\title{
Oviposition of Minstrellus grandis (Lepidoptera: Riodinidae) in a harmful ant-plant symbiosis
}

\author{
Lucas A. KAMINSKI ${ }^{*} \oplus$, Eduardo CARNEIRO², Diego R. DOLIBAINA², Mirna M. CASAGRANDE², \\ Olaf H. H. MIELKE ${ }^{2}$ \\ ' Universidade Federal do Rio Grande do Sul, Instituto de Biociências, Departamento de Zoologia, Av. Bento Gonçalves 9500, 91501-970, Porto Alegre, RS, Brazil \\ 2 Universidade Federal do Paraná, Departamento de Zoologia, Laboratório de Estudos de Lepidoptera Neotropical, Avenida Cel. Francisco H. dos Santos, 100, $81531-$ \\ 980, Curitiba, Paraná, Brazil \\ * Corresponding author: lucaskaminski@yahoo.com.br; (D) https://orcid.org/0000-0002-6468-0960
}

\section{ABSTRACT}

The oviposition behavior of the rare butterfly Minstrellus grandis (Callaghan, 1999) (Lepidoptera: Riodinidae) is recorded for the first time. Two females laid eggs on the old leaves of an unidentified Triplaris Loefl. ex L. (Polygonaceae), a myrmecophytic plant typically known as 'Triplaria' or 'novice' tree, inhabited by aggressive 'taxi' ants of the genus Pseudomyrmex Lund. 1831 (Hymenoptera: Formicidae). These observations suggest that M. grandis caterpillars live associated with one of the most harmful types of Amazon ant-plant symbiosis.

KEYWORDS: Carnivory, myrmecophily, host plant selection, Pachythonina, social parasitism

\section{Oviposição de Minstrellus grandis (Lepidoptera: Riodinidae) em uma perigosa simbiose formiga-planta}

\section{RESUMO}

O comportamento de oviposição da rara borboleta Minstrellus grandis (Lepidoptera: Riodinidae) é registrado pela primeira vez. Duas fêmeas depositaram ovos sobre folhas velhas de uma Triplaris (Polygonaceae) não identificada, uma planta mirmecofítica conhecida popularmente como 'pau-formiga' ou 'novateiro', habitadas por formigas 'taxi' agressivas do gênero Pseudomyrmex (Hymenoptera: Formicidae). Estas observaçôes sugerem que as lagartas de M. grandis vivem associadas com um dos mais perigosos tipos de simbiose formiga-planta da Amazônia.

PALAVRAS-CHAVE: Carnivoria, mirmecofilia, seleção de planta hospedeira, Pachythonina, parasitismo social

The systematics of Riodinidae has advanced in recent years, and robust phylogenetic hypotheses supported by fossilcalibrated dating are now available (Seraphim et al. 2018). This backbone is essential to understand the evolutionary history of this remarkable group of butterflies (Kaminski et al. 2013). The main impediment for the advancement on the knowledge on this family, however, is the lack of information on natural history of species in this group, especially for rare and/or restricted species (DeVries 1997). This is the case for members of the subtribe Pachythonina (Nymphidiini), which comprises 33 species in five genera (Callaghan and Lamas 2004; Hall 2007, 2018; Dias et al. 2015; Gallard 2017; Gallard and Fernandez 2017). Only recently, the first life cycle information for this lineage was revealed, indicating that their caterpillars are myrmecophilous (i.e., live associated with ants), present armored larval morphology and are carnivorous (Medina 2014; Mota et al. 2020). During a collection expedition to the
Serra do Divisor National Park [Parque Nacional da Serra do Divisor (PNSD)], in the western Amazon region (state of Acre, Brazil), we observed, for the first time, the female reproductive behavior of the poorly known riodinid Minstrellus grandis (Callaghan, 1999). This Pachythonina species is rare, known from only five localities in the western Amazon region in Brazil, Bolivia and Peru (Callaghan 1999; Hall 2007). Here we describe its oviposition behavior.

The observations were made in the riparian forest on the right margin of the Moa River, in a frontier-protection deployment area of the Brazilian military forces (Destacamento Especial de Fronteira de Sáo Salvador, 610 Batalháo de Infantaria de Selva) $\left(7^{\circ} 24^{\prime} 47.72^{\prime \prime} S, 73^{\circ} 12^{\prime} 46.55^{\prime \prime W}, 200\right.$ $\mathrm{m})$, about $8 \mathrm{~km}$ east of the border of the PNSD. This region is characterized by a high biological diversity, including riodinid butterflies (Brown and Freitas 2002; Dolibaina et al. 2012, 2015, 2016). Our behavioral observations were 
made on June 19, 2013, between 13:50 and 14:15 h, when two females of $M$. grandis were observed inspecting a Triplaris Loefl. ex L. (Polygonaceae) myrmecophytic plant inhabited by Pseudomyrmex Lund, 1831 ants (Hymenoptera: Formicidae). The females flew slowly and walked along the plant branches, at a height of about three meters from the ground, without attracting the attention of ants (Figure 1a,b). Three oviposition events were observed in both the abaxial and adaxial surfaces of old leaves (Figure 1c). The adult butterflies were collected and are deposited (DZ 51.398 and DZ 51.408) in the collection of the Department of Zoology of Universidade Federal do Paraná, Curitiba, Paraná, Brazil (DZUP). Due to the ant aggressiveness (see Haddad et al. 2009), we were unable to search the Triplaris plant to find possible caterpillars, nor were the eggs and ant vouchers collected. The ants were identified based on behavior, photographs and taxonomist opinion (see Acknowledgments).

Our observations confirm that $M$. grandis uses the myrmecophytic Triplaris plant as oviposition substrate. Although we cannot confirm whether $M$. grandis caterpillars are myrmecophilous, nor whether the type of interaction with ants is commensal, mutualistic or parasitic, the observed behavior suggests a unique life cycle, which may represent the first known case of butterfly caterpillars specialized in Pseudomyrmex ants (Pseudomyrmecinae). These large-eyed arboreal ants have stingers and are quite aggressive, especially those that live associated with myrmecophytes, such as those of the Pseudomyrmex triplarinus (Weddell, 1850) group (sensu Chomicki et al. 2015), that are specialized on Triplaris (Benson 1985; Ward 1999; Chomicki et al. 2015; Sanchez 2015). Known associations between myrmecophilous caterpillars and Pseudomyrmex ants are rare and facultative or antagonic (Fiedler 2001; Kaminski et al. 2012).

The Triplaris-Pseudomyrmex ant-plant symbiosis is widely distributed in the Neotropical lowland forests, but the hotspot for these associations is the western part of the Amazon Basin (Sanchez 2015). Interestingly, the four species of Minstrellus Hall, 2007 are also restricted to the western Amazon (Hall 2007). Although some species of Triplaris and Pseudomyrmex are widely distributed, others have restricted distribution ranges (Ward 1999; Sanchez 2015). Thus, the precise identification of Triplaris-Pseudomyrmex associations is essential to understand their evolutionary history and their relationship with the distribution range and apparent rarity
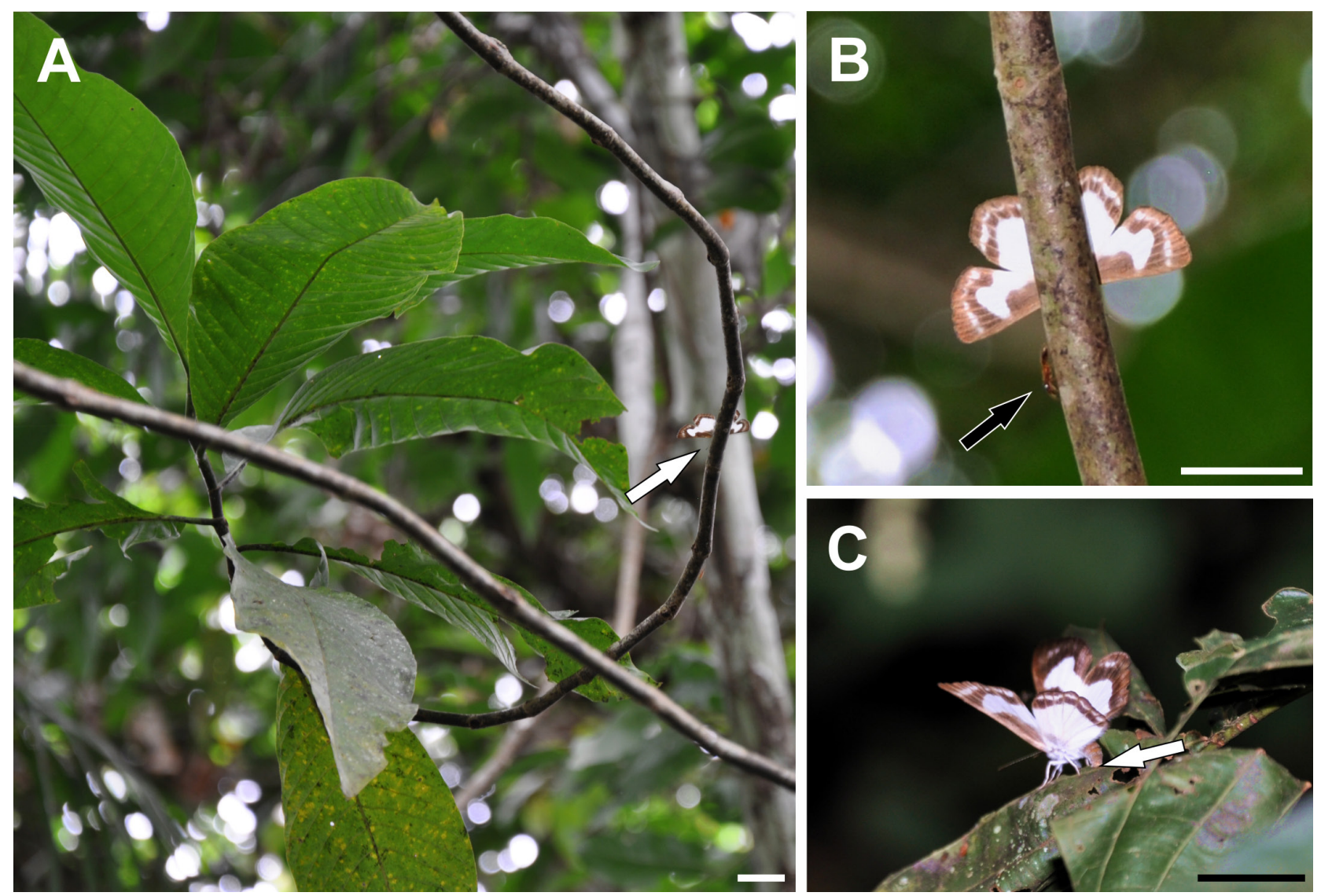

Figure 1. Female behavior of Minstrellus grandis (Lepidoptera: Riodinidae) on a Triplaris (Polygonaceae) plant inhabited by Pseudomyrmex ants by the Moa River, Mâncio Lima, Acre, Brazil. A - host plant, showing female walking on Triplaris branch (arrow); B - detail of female on a branch of the host plant near an ant worker (arrow); $\mathrm{C}-$ female laying eggs on an old leaf of the host plant (arrow). Scale bars $=1.5 \mathrm{~cm}$. This figure is in color in the electronic version. 
of Minstrellus species. It is worth mentioning this was our only record of $M$. grandis in a total of four expeditions to the PNSD, totaling 35 days of sampling effort in September 2011, June 2013, August 2014, and October 2018. This suggests that the occurrence of $M$. grandis may be seasonal, with adults flying for a short period, as reported for some social parasitic species (Fiedler 1998).

Myrmecophilous caterpillars that exploit ant-plant symbiosis are known to exist (Maschwitz et al. 1984). For instance, Triplaris trees inhabited by Azteca Forel, 1878 (Dolichoderinae) ants are attacked by Theope pieridoides C. Felder \& R. Felder, 1865 (Riodinidae) caterpillars (Kaminski et al. 2013). In general, myrmecophilous caterpillars are herbivorous and receive protective benefits from ant partners by inhabiting an enemy-free space (e.g., Kaminski et al. 2010). From herbivorous ancestors, however, some species evolved caterpillars with carnivorous habit and even social parasitism, when caterpillars directly exploit the ants' resources (Pierce et al. 2002). In Pachythonina, it is known that caterpillars of Pachythone xanthe H. Bates, 1868 and Pachythone gigas Godman \& Salvin, 1878 are predators of scale insects associated with aggressive Azteca ants (Medina 2014; Mota et al. 2020). In common, the caterpillars have an armored morphology, perforated cupola organs and tentacular nectary organs with possible appeasing function (Mota et al. 2020). These morphological traits can be preadaptations to live with aggressive ants (see Fiedler 1998; Dupont et al. 2016).

Therefore, it would not be unlikely that $M$. grandis caterpillars are also able to exploit resources from the harmful Triplaris-Pseudomyrmex ant-plant symbiosis. Confirming this hypothesis may add another piece to understand the evolution of carnivory and social parasitism in Pachythonina. Thus, we hope that our report will encourage future fearless efforts to reveal the life cycle of this rare Amazon butterfly.

\section{ACKNOWLEDGMENTS}

We are grateful to former and current PNSD staff, Paulo Oliveira de Sousa, Cleide Rezende de Souza, Diogo Mitsuru Koga and Aécio Silva dos Santos; to Argemiro Oliveira Magalhães (Miro) for his receptivity and support during fieldwork; to Rodrigo Feitosa and Phillip S. Ward for help with ant identification; to Gabriela Pérez-Lachaud, André V. L. Freitas and one anonymous reviewer for their helpful comments on the manuscript; and Coordenaçâo de Aperfeiçoamento de Pessoal de Nível Superior (CAPES) (LAK: PNPD-CAPES), National Geographic Society (\#WW224R-17) (LAK), and Conselho Nacional de Desenvolvimento Científico e Tecnológico (CNPq) (DRD: 171177/2017-7; OHHM: 304639/2014-2; MMC: 302084/2017-7) for the research fellowships granted to the authors.

\section{REFERENCES}

Benson, W.W. 1985. Amazon ant-plants. In: Prance, G.; Lovejoy, T.E. (Eds.). Amazonia. Pergamon Press, New York, p.239-266.

Brown, K.S.; Freitas, A.V.L. 2002. Diversidade Biológica no Alto Juruá: avaliação, causas e manutenção. In: Carneiro da Cunha, M.M.; Almeida, M.B. (Eds.). Enciclopédia da Floresta. O Alto Juruá: Prática e conhecimentos das populaçōes. Companhia das Letras, São Paulo, p.33-42.

Callaghan, C.J. 1999. New taxa of Neotropical Riodinidae (Lepidoptera). Revista Brasileira de Zoologia, 16: 1045-1064.

Callaghan, C.J.; Lamas, G. 2004. Riodinidae. In: Lamas, G. (Ed.). Atlas of Neotropical Lepidoptera, Checklist: Part 4A. HesperioideaPapilionoidea. Scientific Publishers, Gainesville, p.141-170.

Chomicki, G.; Ward, P.S.; Renner, S.S. 2015. Macroevolutionary assembly of ant/plant symbioses: Pseudomyrmex ants and their ant-housing plants in the Neotropics. Proceedings of the Royal Society B, 282: 20152200.

DeVries, P.J. 1997. The Butterflies of Costa Rica and Their Natural History. Vol. II: Riodinidae. Princeton University Press, Princeton, 288p.

Dias, F.M.S.; Dolibaina, D.R.; Mielke, C.G.C.; Mielke, O.H.H.; Casagrande, M.M. 2015. Description of two new species of Pheles Herrich-Schäffer, [1853] and the taxonomic position of two species hitherto included in the genus (Riodinidae: Riodininae). Zootaxa, 3981: 275-283.

Dolibaina, D.R.; Leite, L.A.R.; Dias, F.M.S.; Mielke, O.H.H.; Casagrande, M.M. 2012. An annotated list of Symmachia Hübner, [1819] (Lepidoptera: Riodinidae: Symmachiini) from Parque Nacional da Serra do Divisor, Acre, Brazil, with the description of a new species. Insecta Mundi, 249: 1-11.

Dolibaina, D.R.; Dias, F.M.S.; Mielke, O.H.H.; Casagrande, M.M. 2015. Argyrogrammana Strand (Lepidoptera: Riodinidae) from Parque Nacional da Serra do Divisor, Acre, Brazil, with the description of four new species. Zootaxa, 4028: 227-245.

Dolibaina, D.R.; Dias, F.M.S.; Mielke, O.H.H.; Casagrande, M.M. 2016. Mesene Doubleday (Lepidoptera: Riodinidae) from Parque Nacional da Serra do Divisor, Acre, Brazil, with taxonomic notes and the description of a new species. Zootaxa, 4175: 463-472.

Dupont, S.T; Zemeitat, D.S; Lohman, D.J.; Pierce, N.E. 2016. The setae of parasitic Liphyra brassolis butterfly larvae form a flexible armour for resisting attack by their ant hosts (Lycaenidae: Lepidoptera). Biological Journal of the Linnean Society, 117: 607-619.

Fiedler, K. 2001. Ants that associate with Lycaeninae butterfly larvae: diversity, ecology and biogeography. Diversity and Distributions, 7: 45-60.

Fiedler, K. 1998. Lycaenid-ant interactions of the Maculinea type: tracing their historical roots in a comparative framework. Journal of Insect Conservation, 2: 3-14.

Gallard, J.-Y. 2017. Les Riodinidae de Guyane. Tezida, Bulgaria, 191p.

Gallard, J-Y.; Fernandez, S. 2017. Des postes territoriaux des Riodinides en Guyane: découverte de deux nouvelles espèces (Lepidoptera, Riodinidae). Bulletin de la Société entomologique de France, 122: 429-436. 
Haddad Jr., V.; Bicudo, L.R.H.; Fransozo, A. 2009. The Triplaria tree (Triplaris spp) and Pseudomyrmex ants: a symbiotic relationship with risks of attack for humans. Revista da Sociedade Brasileira de Medicina Tropical, 42: 727-729.

Hall, J.P.W. 2007. Phylogenetic revision of the new neotropical riodinid genus Minstrellus (Lepidoptera: Riodinidae). Annals of the Entomological Society of America, 100: 773-786.

Hall, J.P.W. 2018. A Monograph of the Nymphidiina (Lepidoptera: Riodinidae: Nymphidiini): Phylogeny, Taxonomy, Biology, and Biogeography. Entomological Society of Washington, Washington DC., 990p.

Kaminski, L.A.; Freitas, A.V.L.; Oliveira, P.S. 2010. Interaction between mutualisms: ant-tended butterflies exploit enemyfree space provided by ant-treehopper associations. American Naturalist, 176: 322-334.

Kaminski, L.A.; Mota, L.L.; Freitas, A.V.L.; Moreira, G.R.P. 2013. Two ways to be a myrmecophilous butterfly: natural history and comparative immature-stage morphology of two species of Theope (Lepidoptera: Riodinidae). Biological Journal of the Linnean Society, 108: 844-870.

Kaminski, L.A.; Rodrigues, D.; Freitas, A.V.L. 2012. Immature stages of Parrhasius polibetes (Lepidoptera: Lycaenidae): host plants, tending ants, natural enemies, and morphology. Journal of Natural History, 46: 645-667.

Maschwitz, U.; Schroth, M.; Hänel, H.; Pong, T.Y. 1984. Lycaenids parasitizing symbiotic plant-ant partnerships. Oecologia, 64: 78-80.

\section{ERRATA}

On page 256, where it reads:

"Triplaris sp." and "Pseudomyrmex sp."

Please read as:

"Triplaris Loefl. ex L." and "Pseudomyrmex Lund, 1831"

On page 257, where it reads:

", when they occur (Fiedler 2001)"

Please read as:

"or antagonic (Fiedler 2001; Kaminski et al. 2012)"

On page 258, where it reads:

“Dolibaina, D.R.; Dias, F.M.S.; Mielke, O.H.H.; Casagrande, M.M. 2015. Mesene Doubleday (Lepidoptera: Riodinidae) from Parque Nacional da Serra do Divisor, Acre, Brazil, with taxonomic notes and the description of a new species. Zootaxa, 4175: 463-472."

Please read as:

"Dolibaina, D.R.; Dias, F.M.S.; Mielke, O.H.H.; Casagrande, M.M. 2016. Mesene Doubleday (Lepidoptera: Riodinidae) from Parque Nacional da Serra do Divisor, Acre, Brazil, with taxonomic notes and the description of a new species. Zootaxa, 4175: 463-472."

On page 258, in the References, after Kaminski et al. 2013, please add:

"Kaminski, L.A.; Rodrigues, D.; Freitas, A.V.L. 2012. Immature stages of Parrhasius polibetes (Lepidoptera: Lycaenidae): host plants, tending ants, natural enemies, and morphology. Journal of Natural History, 46: 645-667."

Acta Amazonica 50(4): 368-368

This is an Open Access article distributed under the terms of the Creative Commons Attribution License, which permits unrestricted use,

distribution, and reproduction in any medium, provided the original work is properly cited. 